\title{
Factors That Influence UMKM Taxpayer Compliance After Establishment of Government Regulation Number 23 Year 2018 (Empirical Study in Rokan Hulu Regency)
}

\author{
Nurhayati ${ }^{1,}$ Nofrianty ${ }^{2}$ \\ ${ }^{1.2}$ FacultyEconomi University PasirPengaraian, Riau, Indonesia \\ email: nurhayati170312@gmail.com
}

\begin{abstract}
From the amendment to this regulation, the thing that becomes the spotlight of taxpayers is by changing the final $\mathrm{PPh}$ rate from $1 \%$ to $0.5 \%$, this policy aims to stimulate UMKM business and besides, the government also hopes that MSMEs can easily carry out their tax obligations and provide relief tax rates aimed at individual taxpayers and corporate taxpayers in the form of cooperatives, limited partnership, firms and limited liability companies that own and receive gross receipts do not exceed Rp. $4,800,000,000$ in one year. The purpose of this study was to determine the effect of Tax Rates, Socialization and Understanding on the implementation of UMKM Taxpayer Compliance Post Government Regulation No. 23 of 2018 both partially and simultaneously. This type of research is causative research, with the population being MSME taxpayers registered as taxpayers in RokanHulu district as many as 135 UMKM taxpayers for micro scale. Data collection techniques using documentation and questionnaires.Data analysis techniques using multiple linear regression analysis, coefficient of determination and partial and simultaneous tests. The results of research for the tax rate partially affect the compliance of taxpayers with a significance of under 5\%. This shows that whether or not the taxpayer adheres is influenced by the intention of the taxpayer himself in taking action to comply with tax obligations. Parsing socialization influences taxpayer compliance with significantly below 5\%. This shows that the more socialization carried out by the tax authorities, the compliance of individual taxpayers will increase. Understanding has a partial effect on taxpayer compliance with significantly below 5\%. This shows that increasing taxpayer knowledge provided by the government regarding Government Regulation No. 23 of 2018 to taxpayers, the understanding of taxes, especially taxes for UMKM will be even better.
\end{abstract}

Keywords-Tax Rates, Socialitation, Understanding, UMKM Taxpayer Compliance.

IJoASER,Volume 2, Issue 2, July,2019

DOI: 10.33648/ijoaser.v2i2.30

Copyriht: STAI Al-Furqan Makassar,Indonesia

Content License: CC-BY-SA 


\section{INTRODUCTION}

Government Regulation Number 23 Year 2018 is about income tax on business income received or obtained by taxpayers who have a certain gross circulation. This regulation was issued by the Government on July 1, $2019,[1]$ this regulation was issued to replace the previous regulation, namely Government Regulation Number 46 of 2013 which is considered to have a number of deficiencies, so it needs to be adjusted to the current economic conditions.[2]

From the amendment to this regulation, the thing that becomes the spotlight of taxpayers is by changing the final $\mathrm{PPh}$ rate from $1 \%$ to $0.5 \%$, this policy aims to stimulate UMKM business and besides, the government also hopes that MSMEs can easily carry out their tax obligations and provide relief tax rates aimed at individual taxpayers and corporate taxpayers in the form of cooperatives, limited partnership, firms and limited liability companies that own and receive gross receipts do not exceed Rp. $4,800,000,000$ in one year.[1]

Research conducted by Luh Putu Gita Cahyani and Naniek Novairishows that tax rates, understanding of taxation and tax sanctions have a positive effect on the compliance of the basic UMKM taxpayers simultaneously and partially[3]. And the research by nurhayati (2019) awareness and perception of taspayers simultaneously has an influence on the successs of advertisement tax revenue.[4]

With a self-assessment tax collection system which means that taxpayers must be fully responsible for their obligations in tax payments, tax reporting and tax notification owed to the government in accordance with applicable tax laws and in accordance with the needs of the taxpayer. This system really requires the awareness of a taxpayer to obey his obligations, as well as increasing taxpayer knowledge and insight regarding tax systems and regulations that apply in Indonesia, and to increase the taxpayer's knowledge, the government must also aggressively disseminate and understand taxpayers related to changes in tax rates from $1 \%$ to $0.5 \%$.[1]

Taxpayer compliance is the extent to which taxpayers can carry out tax obligations properly and correctly taxation regulations.[5] Tax rates, outreach and understanding include factors that affect taxpayer compliance. According to Sudirman and Amirudin, The tax rate is a stipulation of the percentage (\%) or amount (rupiah) of tax that must be paid by taxpayers in accordance with the tax base or tax object.[6]

While socialization is the learning of values, norms and behavior patterns expected by groups as a form of reform so that effective organization. In order to achieve its objectives, the socialization or counseling activities in taxation are divided into three focus, namely the activities of prospective taxpayers, the socialization activities for new taxpayers, and the socialization activities for registered taxpayers [7]. And according to (Pancawati Hardiningsih) [8] states an understanding of tax 
regulations is the understanding of taxpayers about taxation regulations is a way for taxpayers to understand existing tax regulations.

Dissemination is mandatory to increase the knowledge and understanding of people who become taxpayers of the current taxation system. Lack of socialization will result in low taxpayer knowledge and also affect tax revenue in Indonesia. Besides socialization, the government must also increase the understanding of taxpayers about tax rates. The tax rate is the percentage used as a basis in calculating the amount of tax that must be deposited, a lack of understanding will result in the non-compliance of taxpayers with existing tax regulations.

Based on the background description of the problem above, the author is interested in conducting research with the title "Factors Affecting UMKM Taxpayer Compliance Post Government Regulation Number 23 Year 2018 (Empirical Study in Rokan Hulu Regency)".

\section{METHOD}

The object of research is the UMKM taxpayer in RokanHulu district. The research population in this study is the UMKM taxpayers who are registered in the Department of Cooperatives UKM Transmigration and Workers of RokanHulu Regency as many as 135 specifically micro-scale UMKM Taxpayers. Determination of the sample using the accidental sampling method with the Slovin formula, Sujarweni.[9]The criterion chosen to be the respondent of this test was the UMKM taxpayer who had a turnover not exceeding Rp. 4,800,000,000. The data source is primary data in the form of a questionnaire using a Likert scale. The data analysis technique used in this study is a multiple linear regression analysis technique which functions to determine the linear relationship between two or more variables, Regression Coefficient and Hopotesis Testing using Partial Test and Simultaneous Test.

\section{RESULTS}

\section{A. Section One}

\section{Descriptive Statistics of Respondents}

The description of the characteristics of UMKM taxpayers is in accordance with Government Regulation Number 23 of 2018.[10] Based on a questionnaire that has been distributed by determining the sample using the accidental sampling method with the Slovin formula. With the results of 101 respondents.

\section{Descriptive Statistics Of Research Variables}

Descriptive analysis of the data taken for this study is the UMKM taxpayers for micro scale as many as 101 people spread over four subdistricts in RokanHulu Regency in the following table:

\footnotetext{
IJoASER,Volume 2, Issue 2, July,2019

DOI: 10.33648/ijoaser.v2i2.30

Copyriht: STAI Al-Furqan Makassar,Indonesia

Content License: CC-BY-SA
} 
Table 2. Number of Respondents In Rokan Hulu Regency

\begin{tabular}{|c|l|c|}
\hline No & \multicolumn{1}{|c|}{ Districts } & Number Respondents \\
\hline 1 & Rambah & 43 People \\
\hline 2 & RambahHilir & 18 People \\
\hline 3 & Kepenuhan & 25 People \\
\hline 4 & KepenuhanHulu & 15 People \\
\hline & Amount & 101 People \\
\hline
\end{tabular}

Source: Processed Data, 2019

Descriptive variables in the descriptive statistics used in this study include the minimum, maximum, mea and standard deviation values of one dependent variable and the independent variable. Descriptive statistics relate to the collection and ranking of data. This descriptive statistic illustrates the character of the sample used in this study. The following are descriptive statistics for each variable in this study:

Table 3. Descriptive Statistics

\begin{tabular}{|l|r|r|r|r|r|}
\hline & \multicolumn{1}{|c|}{ N } & \multicolumn{1}{c|}{ Minimum } & Maximum & \multicolumn{1}{c|}{ Mean } & Std. Deviation \\
\hline Tarif_Pajak & 101 & 10,00 & 23,00 & 17,7228 & 3,37674 \\
Sosialisasi & 101 & 11,00 & 25,00 & 18,6040 & 2,86035 \\
Pemahaman & 101 & 12,00 & 23,00 & 18,0693 & 3,05043 \\
Kepatuhan_Wajib_Pajak & 101 & 13,00 & 25,00 & 18,4356 & 2,76194 \\
Valid N (listwise) & 101 & & & & \\
\hline
\end{tabular}

Source: Processed Data, 2019

\section{B. Section Two}

\section{Multiple Linear Regression Analysis}

Multiple Regression analysis is used to predict the magnitude of the influence of the variable tax rates, Socialization, Understanding Of TaxpayerCompliance. The result of SPSS output can be seen in the following table:

Table 4. Multiple Regression Results

\begin{tabular}{|c|c|c|}
\hline \multirow[t]{2}{*}{ Model } & \multicolumn{2}{|c|}{ Unstandardized Coefficients } \\
\hline & B & Std. Error \\
\hline (Constant) & 3,489 & 1,123 \\
\hline Tarif_Pajak & , 188 & ,069 \\
\hline Sosialisasi & , 188 & ,084 \\
\hline Pemahaman & ,449 & 074 \\
\hline
\end{tabular}

Source: Processed Data, 2019

From the calculation results obtained in the multiple linear regression equation as follows:

$\mathrm{Y}=3,489+0,188 \mathrm{X} 1+0,188 \mathrm{X} 2+0,449 \mathrm{X} 3$. 
The coefficient of multiple determination aims to see the effect of the independent variable on the dependent variable. Result $\mathrm{R}^{2}$ this is in between $0<\mathrm{R}^{2}<1$, this means that the results of the $\mathrm{R} 2$ determination test are as follows:

Table 5. Model Summary Determination Test Results $\mathbf{R}^{2}$

\begin{tabular}{|cc|c|c|c|c|}
\hline Model & $\mathbf{R}$ & R Square & $\begin{array}{c}\text { Adjusted R } \\
\text { Square }\end{array}$ & $\begin{array}{c}\text { Std. Error of } \\
\text { the Estimate }\end{array}$ \\
\hline dimension0 & 1 &, $817^{\mathrm{a}}$ &, 667 &, 657 & 1,61707 \\
\hline
\end{tabular}

Source: Processed Data, 2019

The test results are done using the SPSS Program, then the coefficient of determination (R2) is known that is R Square obtained by 0.667 . This result means that $66.7 \%$ of taxpayer compliance can be explained that the variable tax rate, socialization and understanding give a joint effect of $66.7 \%$ of the taxpayer compliance variable as the dependent variable. While the rest is $(100 \%-66.7 \%=33.3 \%)$ tax compliance is explained by other variables not examined in this study.

\section{Partial Test (t)}

Partial ot test is used to test the significant relationship between variable $\mathrm{X}$ and $\mathrm{Y}$. The following test can be seen in the following table:

Tabel 6. Result Partial (t)

\begin{tabular}{|c|c|c|c|l|}
\hline Variable & $\mathbf{t}_{\text {hitung }}$ & $\mathbf{t}_{\text {tabel }}$ & Sig & \multicolumn{1}{|c|}{ Information } \\
\hline Take Rates (X1) & 2,735 & 1,984 & 0,007 & Significant Affect \\
\hline Sosialitation (X2) & 2,230 & 1,984 & 0,028 & Significant Affect \\
\hline Understanding (X3) & 6,028 & 1,984 & 0,000 & Significant Affect \\
\hline
\end{tabular}

Source:Processed Data, 2019

Table 7. Result Partial f ANOVA $^{\text {b }}$

\begin{tabular}{|rl|r|r|r|r|r|}
\hline \multicolumn{1}{|l|}{ Model } & & Sum of Squares & df & Mean Square & \multicolumn{1}{c|}{ F } & \multicolumn{1}{c|}{ Sig. } \\
\hline 1 & Regression & 509,185 & 3 & 169,728 & 64,908 &, $000^{\mathrm{a}}$ \\
& Residual & 253,647 & 97 & 2,615 & & \\
Total & 762,832 & 100 & & & \\
\hline
\end{tabular}

Sumber: Data Olahan, 2019

IJoASER,Volume 2, Issue 2, July,2019

DOI: 10.33648/ijoaser.v2i2.30

Copyriht: STAI AI-Furqan Makassar,Indonesia

Content License: CC-BY-SA 


\section{Discussion \\ Influence Of Tax Rates On Taxpayer Compliance}

Based on data analysis, it can be concluded that the value of the tax rate is $2.736>1.984$, it can be determined that $\mathrm{Ho}$ is accepted and $\mathrm{Ha}$ is rejected. Thus it was concluded that there was a significant influence between tax rates on taxpayer compliance at a significance level of under $5 \%$. The results of this study support research conducted by Luh Putu Gita Cahyani and Naniek Novianri[3] which states that tax rates have a positive effect on UMKM taxpayer compliance. This test also supports the decision making process, which is whether the taxpayer must comply or not is influenced by the intention of the taxpayer himself in taking action to comply with tax obligations.

\section{InfluenceSocialization On Taxpayer Compliance}

Based on data analysis, it can be seen that the socialization value of $2.230>\mathrm{t}$ table 1.984, it can be determined that Ho is accepted and $\mathrm{Ha}$ is rejected. Thus it was concluded that there was a significant influence between the socialization of taxpayer compliance at a significance level of under 5\%. The results of this study support the research conducted by Debby Cornelia and Icha Fajrian [11] which states that the socialization has a positive effect on compliance after the Government Regulation No. 23 of 2018 is applied to MSMEs in Palembang. This shows that the more socialization carried out by the tax authorities, the compliance of individual taxpayers will increase.

\section{Influence Of Understanding On Taxpayer Compliance}

Based on data analysis, it can be concluded that the value of understanding is 6.028 $>1.984$ then it can be determined that Ho is accepted and $\mathrm{Ha}$ is rejected. Thus it was concluded that there was a significant influence between the understanding of taxpayer compliance at a significance level of under 5\%. The results of this study support research conducted by Luh Putu Gita Cahyani and Naniek Novianri[3] which states that understanding has a positive effect on UMKM taxpayer compliance. and also supports research conducted by Debby Cornelia and Icha Fajrian [11] which states that understanding has a positive effect on compliance after the adoption of Government Regulation No, 23 of 2018 on UMKM in Palembang. This also shows that the taxpayer's knowledge given by the government regarding Government Regulation no. 23 of 2018 to taxpayers, the understanding of taxes, especially taxes for UMKM will be increasingly better Influence understanding

From the $\mathrm{F}$ test results obtained that the value of Fcount $>\mathrm{F}$ table $(64.908>2.70)$ with a significance level of $0.000<0.05$. Because the significant level is less than 0.05 then $\mathrm{Ha}$ is accepted, the calculation shows that the variable tax rate, socialissi, and understanding simultaneously have a significant effect on taxpayer compliance. The results support the results of research conducted by Luh Putu Gita Cahyani and Naniek Novianri (2019) which states that tax rates, understanding have a positive effect on UMKM taxpayer compliance. and also supports research conducted by Debby Cornelia and Icha Fajrian (2019) which states that the Socialization and Understanding has a positive effect on Compliance After Government Regulation No. 23 of 2018 is applied to UMKM in Palembang. 


\section{IV.CONCLUSION}

The conclusions obtainer in this study are:

1. Tax rates affect taxpayer compliance with a significance of under $5 \%$. This shows that whether or not the taxpayer adheres is influenced by the intention of the taxpayer himself in taking action to comply with tax obligations.

2. Socialization influences taxpayer compliance with significantly below $5 \%$. This shows that the more socialization carried out by the tax authorities, the compliance of individual taxpayers will increase.

3. Understanding affects the Compliance of taxpayers significantly under $5 \%$. This shows that increasing taxpayer knowledge provided by the government regarding Government Regulation No. 23 of 2018 to taxpayers, the understanding of taxes, especially taxes for UMKM will be even better.

\section{REFERENCES}

[1] D. Pajak, Perarutan Pemerintah Republik Indonesia Nomor 23 Tahun 2018 Tentang Pajak Penghasilan Atas Penghasilan Usaha Diterima Atau Diperoleh Pajak Yang Dimiliki Peredaraan Bruto Tertentu. 2018.

[2] D. Pajak, Peraturan Pemerintah Nomor 46 Tahun 2013 tentang Pajak Penghasilan Atas Penghasilan dari Usaha Yang Diterima atau Diperoleh Wajib Pajak yang Memiliki Peredaran Bruto Tertentu. 2013.

[3] D. Putu Gita Cahyani, Luh, "Pengaruh Tarif Pajak, Pemahaman Perpajakan, dan Sanksi Perpajakan Terhadap Kepatuhan wajib Pajak UMKM.," 2019.

[4] Nurhayati, "Faktor-Faktor Yang Mempengaruhi Keberhasilan Penerimaan Pajak Reklame (Studi Empris Di Kabupaten Rokan Hulu). Universitas Pasir Pengaraian," 2019.

[5] F. Ahmad Mustofa, "Pengaruh Pemahaman Peraturan Perpajakan, Tarif Pajak Dan Asas Keadilan Terhadap Kepatuhan Wajib Pajak (Studi Pada Wajib Usaha Mikro Kecil dan Menengah yag Berada di Wilayah Kerja Kantor Pelayanan Pajak Pratama Batu Setelah Diberlakukannya Peraturan Pemeri," 2016.

[6] A. \& Sudirman, Perpajakan Pendekatan Teori dan Praktik di Indonesia. 2012.

[7] T. A. . Heryanto, M., "Pengaruh Kesadaran Wajib Pajak, Kegiatan Sosialisati Perpajakan, dan Pemeriksaan Pajak Terhadap Penerimaan Pajak Penghasilan di KPP Pratama Surabaya Sawahan. Tax and Accounting Review, 1(1), hal. 125-133.," 2013.

[8] P. Hardiningsih, "Faktor-Faktor Yang Mempengaruhi Kemauan Membayar Pajak Wajib Pajak Orang Pribadi Yang Melakukan Pekerjaan Bebas. Universitas Jenderal Soedirman: Purwokerto.," 2011. 
[9] Sujarweni, Metode Penelitian: Lengkap, Praktis, dan Mudahnya. 2014.

[10] D. K. U. T. dan T. K. K. R. Hulu, "Data UMKM Kabupaten Rokan Hulu," 2019.

[11] D. Cornelia Angelia, "Pengaruh Sosialisasi Dan Tingkat Pemahaman Terhadap Kepatuhan Setelah Penerapan Peraturan Pemeritnah No. 23 Tahun 2018 Pada Pelaku UMKM di Kota Palembang. STIE Multi Data: Palembang," 2019. 